Gut, 1988, 29, 319-324

\title{
Source of endogenous arachidonate and 5-lipoxygenase products in human neutrophils stimulated by bradykinin and A23187
}

\author{
O H NIELSEN, K BUKHAVE, I AHNFELT-RØNNE, AND J RASK-MADSEN . \\ From the Department of Medical Gastroenterology C, Herlev Hospital, University of Copenhagen, Department \\ of Pharmacology, Leo Pharmaceutical Products, Ballerup, and Section of Gastroenterology, Department of \\ Medicine B, Bispebjerg Hospital, University of Copenhagen, Denmark
}

SUMMARY The lipoxygenase products of arachidonic acid (AA) metabolism, 5-hydroxyeicosatetraenoic acid (5-HETE) and leucotriene $B_{4}\left(L_{T B}\right)$, are considered to have an important pathophysiological role in inflammatory bowel disease by stimulating the inflammatory response and by contributing to the diarrhoea. The present studies were designed to investigate the effect of the physiological stimulants bradykinin (BK) and 5-hydroxytryptamine (5-HT), in addition to the influence of the calcium ionophore $\mathbf{A 2 3 1 8 7}$, on the source of $\mathrm{AA}$ release and 5-lipoxygenation in human neutrophils (PMNs) in vitro. This was done to elucidate the specificity of the mechanism by which PMNs respond to physiological, extracellular $\mathrm{Ca}^{2+}$ dependent agonists. The results of the study indicate that stimulation of $1-{ }^{14} \mathrm{C}$-AA-prelabelled PMNs with BK liberates AA mainly from phosphatidylinositol, while A23187 causes release of AA from phosphatidylcholine, phosphatidylethanolamine, and possibly phosphatidylserine. Furthermore BK $\left(10^{-9}-10^{-6} \mathrm{M}\right)$ dose-dependently stimulated the formation of 5-HETE and $\mathrm{LTB}_{4}$, reaching a maximum at $10^{-7} \mathrm{M}$, while 5 -HT $\left(10^{-8}-10^{-4} \mathrm{M}\right)$ released only negligible amounts of eicosanoids, similar to those observed in control

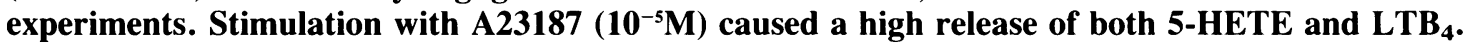
These results offer evidence that BK, but not 5-HT, initiates formation of lipoxygenase products by binding to specific receptors on the external surface of PMNs, whereas A23187 accelerates 5lipoxygenation through mechanisms which do not involve a cell surface receptor.

In the diseased colon eicosanoids may potentially contribute to inflammation, in addition to alterations in fluid and electrolyte transport, intestinal motor activity, and mucosal blood flow.' Thus previous studies have observed increased local formation of cyclooxygenase - and lipoxygenase products of arachidonic acid (AA) metabolism in experimental models of colonic inflammation ${ }^{23}$ and in man with ulcerative colitis (UC). ${ }^{+7}$

Although neutrophils (PMNs), which are abundant in the inflamed colonic mucosa,${ }^{8}$ are considered to metabolise AA via the cyclooxygenase pathway, their major AA metabolites are the lipoxygenase products, 5-hydroxyeicosatetraenoic acid (5-HETE) and leucotriene $\mathrm{B}_{4} .^{{ }^{11}}$ The latter substance is a potent chemotactic agent that pro-

Address for correspondence: Dr Ole Haagen Nielsen, Department of Medical Gastroenterology C, Herlev Hospital, DK-2730 Herlev, Denmark.

Received for publication 13 August 1987. motes migration and stimulates aggregation and degranulation of neutrophils, in addition to release of lysosomal enzymes and superoxide production. ${ }^{11} 12$

Arachidonic acid is liberated not only by phospholipase $A_{2}$, however, but also by phospholipase $C .^{13}$ Thus the stimulation of AA metabolism by physical (mechanical, irradiation) or chemical (hypoxia, 'free radicals') damage, which does not require a specific receptor, is associated with an increased turnover of phosphatidylcholine (PC), phosphatidylethanolamine (PE), and phosphatidylinositol (PI) and catalysed by phospholipase $\mathrm{A}_{2} .^{914}$ is $\mathrm{On}$ the other hand, the mucosal infiltrate per se may also promote eicosanoid formation and diarrhoea by releasing agents, such as bradykinin (BK) and 5-hydroxytryptamine (5-HT), that function as extracellular stimulants of membrane bound phospholipase $\mathrm{C}$, which hydrolyses PI by a series of reactions involving diacylglycerol and monoacylglycerol lipases. ${ }^{15-17}$ This receptor linked breakdown 
of PI leads to formation of diacylglycerol, inositoltriphosphate, as well as AA metabolism, ${ }^{131518}$ which appears to be integrated with calcium mobilisation and cyclic GMP production in a single receptor cascade system, ${ }^{19}$ without involving cyclic AMP. Diacylglycerol acts as an essential cofactor for protein kinase $\mathrm{C},{ }^{19}$ while inositoltriphosphate functions as a messenger to mobilise calcium from an intracellular site, ${ }^{13}$ and AA metabolites, such as prostaglandins of the $\mathrm{E}$ type, act as calcium ionophores to increase intracellular calcium by opening calcium channels. ${ }^{1520}$

The present study was carried out to study the effect of physiologic $\mathrm{Ca}^{2+}$ dependent agonists on the source of endogenous $\mathrm{AA}$ and 5-lipoxygenation in human PMNs in vitro. $1{ }^{14} \mathrm{C}$-AA-prelabelled PMNs were stimulated, therefore, by BK and 5-HT and the results were compared with those obtained by using the calcium ionophore, A23187, to elucidate the specificity of the mechanism by which PMNs respond to extracellular, $\mathrm{Ca}^{2+}$ dependent agonists.

\section{Methods}

CELL ISOLATION

Venous blood (EDTA $10 \mathrm{mM}$ ) was obtained from the cubital vein of healthy volunteers who had taken no drugs for at least two weeks. Purification of the cells were initiated within 30 minutes after blood sampling.

Leucocytes were isolated by a modification of the method described by Böyum: $:^{21}$ (1) erythrocytes were sedimented for 45 minutes at $20^{\circ} \mathrm{C}$ with methylcellulose $(0 \cdot 8 \%),(2)$ the 'buffy coat' leucocytes were washed twice in Gey's solution in human albumin $(2 \%),(3)$ mononuclear leucocytes and platelets were separated from neutrophils by gradient centrifugation using Lymfoprep ${ }^{R}$ (Nygaard and Co, Oslo, Norway), and (4) contaminating erythrocytes were removed by hypotonic lysis with $\mathrm{NaCl}(0 \cdot 2 \%)$.

Isolated PMNs (median recovery $44 \%$, more than $97 \%$ purity) were washed twice and resuspended in the culture medium RPMI 1640 (Gibco Ltd, Renfrewshire, Scotland) with hepes buffer $(25 \mathrm{mM})$ and glutamine $(2 \mathrm{mM})$ under a stream of $5 \%$ carbondioxide and $95 \%$ atmospheric air.

\section{A GONISTS}

Solutions of BK or 5-HT (Sigma Inc, St Louis, MO, USA) were prepared in Gey's solution shortly before use in physiologically relevant concentrations: $10^{-9}$ to $10^{-6} \mathrm{M}$ for $\mathrm{BK}^{22}$ and $10^{-8}$ to $10^{-4} \mathrm{M}$ for $5-\mathrm{HT}^{23}$

The calcium ionophore, A23187 (Calbiochem, La Jolla, CA, USA) $\left(10^{-5} \mathrm{M}, 15 \mathrm{~min}\right)$, was included as a positive control and a comparator of eicosanoid production and AA mobilisation, respectively.
ARACHIDONIC ACID METABOLISM

Neutrophils $\left(5 \times 10^{6}\right.$ cells $\left./ \mathrm{ml}\right)$ were incubated with $1-{ }^{14} \mathrm{C}$-AA $\left(37 \times 10^{3}\right.$ Becquerel $(\mathrm{Bq}) / 5 \times 10^{6}$ PMNs, $2.2 \times 10^{9} \quad \mathrm{~Bq} / \mathrm{mmol}$, Amersham International, Buckinghamshire, England) for five hours at $37^{\circ} \mathrm{C}$ to achieve steady state conditions for the labelling of intracellular pools of AA. Excess AA was removed by washing with Gey's solution. Bradykinin or 5-HT were added after a 15 minute equilibration period.

Time course experiments were carried out to determine the lag until optimum stimulation. Isolation of extracellular radiolabelled metabolites was carried out by centrifugation $\left(8 \times 10^{3} \mathrm{G}, 1 \mathrm{~min}\right)$ of the cells through dibutyl-phthalate:dinonyl-phthalate; $3: 1$ (density $1.033 \mathrm{~g} / \mathrm{ml}$ ), and extraction according to Folch. ${ }^{9}$ The radioactive metabolites, 5-HETE and $\mathrm{LTB}_{4}$, were separated by thin layer chromatography and quantified by autoradiography and laser densitometry as previously described. ${ }^{9}$

To define the phospholipid groups, from which AA was mobilised, thin layer chromatography analysis of lipid extracts from total cell suspensions was carried out as previously described in detail. ${ }^{9}$ Shortly, the suspensions were extracted ad modum Folch ${ }^{y}$ and the organic phases evaporated in a stream of nitrogen. The residues were applied to thin-layer chromatography (TLC) using $\mathrm{CH}_{2} \mathrm{Cl}_{2}$ :methanol: 2-propanol:0 $25 \% \mathrm{KCl}$ :ethylacetate $(30: 9: 25: 6: 18)$ as a developing solvent. After autoradiography of the TLC-plates, which were exposed for one week, quantification of the radioactive spots were performed by laser densitometry. Identification of the different phospholipids was performed by cochromatography with pure standards. ${ }^{9}$

The specific activity of released $\mathrm{LTB}_{4}$ was determined by high pressure liquid chromatography as previously described. ${ }^{79}$

\section{ETHICS}

Informed consent was obtained from all healthy volunteers and the study was approved by the Scientific Ethics Committee of the Copenhagen County.

STATISTICAL ANALYSIS

Results are given as medians with ranges in brackets. Wilcoxon's test for paired and unpaired observations were applied. A p value of less than $0.05(2 \alpha)$ was considered significant.

\section{Results}

In a preliminary series of experiments stimulation with $\mathrm{BK}$ for 10 minutes was found to cause optimum conditions (Fig. 1). For BK the release of radioactivity from $1-{ }^{-14} \mathrm{C}$-prelabelled PMNs, in the concen- 


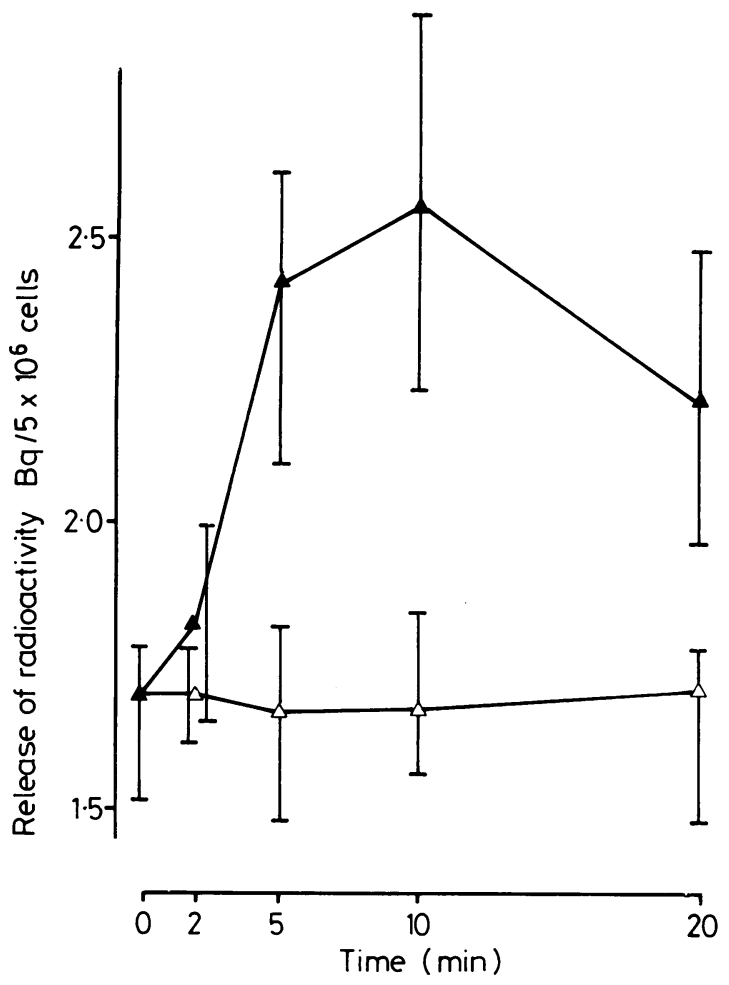

Fig. 1 Time course experiments for stimulation of $1-{ }^{14} \mathrm{C}$ arachidonic acid labelled neutrophils with bradykinin $\left(10^{-7}\right.$ $M)(\Delta)$ or 5-hydroxytryptamine $\left(10^{-7} M\right)(\triangle)$. Values are given as medians with $Q_{50}$ ranges for 6 experiments.

tration range tested, reached a maximum at $10^{-7} \mathrm{M}$ (Table 1). The total amount of radioactivity released - that is, AA and its metabolites, was $2.6 \times 10^{2}$ $\mathrm{Bq} / 5 \times 10^{6}$ cells $\left(2 \cdot 0-3 \cdot 5 \times 10^{2} \mathrm{~Bq} / 5 \times 10^{6}\right.$ cells $)$ corresponding to $7 \cdot 8 \%(5 \cdot 0-11.7 \%)$ of the $1-{ }^{14} \mathrm{C}-\mathrm{AA}$ incorporated into phospholipids compared with a release of $1.7 \times 10^{2} \mathrm{~Bq} / 5 \times 10^{6}$ cells or approximately $5 \%$ of the $1{ }^{14} \mathrm{C}$-AA incorporated into phospholipids in non-stimulated cells $(\mathrm{p}<0 \cdot 01)$ (Table 2$)$, whereas stimulation with the calcium ionophore, A23187, resulted in a total release of $6.7 \times 10^{2} \mathrm{~Bq} / 5 \times 10^{6}$ cells

Table 1 Total amount of radioactivity released from $1-{ }^{14} \mathrm{C}$ arachidonic acid prelabelled neutrophil granulocytes $\left(10^{2}\right.$ $B q / 5 \times 10^{6}$ cells) after stimulation with bradykinin. Values are given as medians with ranges in brackets

\begin{tabular}{lccccc}
\hline \multicolumn{5}{c}{ Bradykinin concentration $(M)$} \\
\cline { 2 - 5 } & $10^{-6}$ & $10^{-7}$ & $10^{-8}$ & $10^{-9}$ & $10^{-\infty}$ \\
\hline Radioactivity & $1 \cdot 8$ & $2 \cdot 6$ & $1 \cdot 9$ & $1 \cdot 6$ & $1 \cdot 7$ \\
& $(1 \cdot 5-2 \cdot 5)$ & $(2 \cdot 0-3 \cdot 5)$ & $(0 \cdot 9-2 \cdot 3)$ & $(0 \cdot 7-2 \cdot 0)$ & $(0 \cdot 7-2 \cdot 1)$ \\
\hline
\end{tabular}

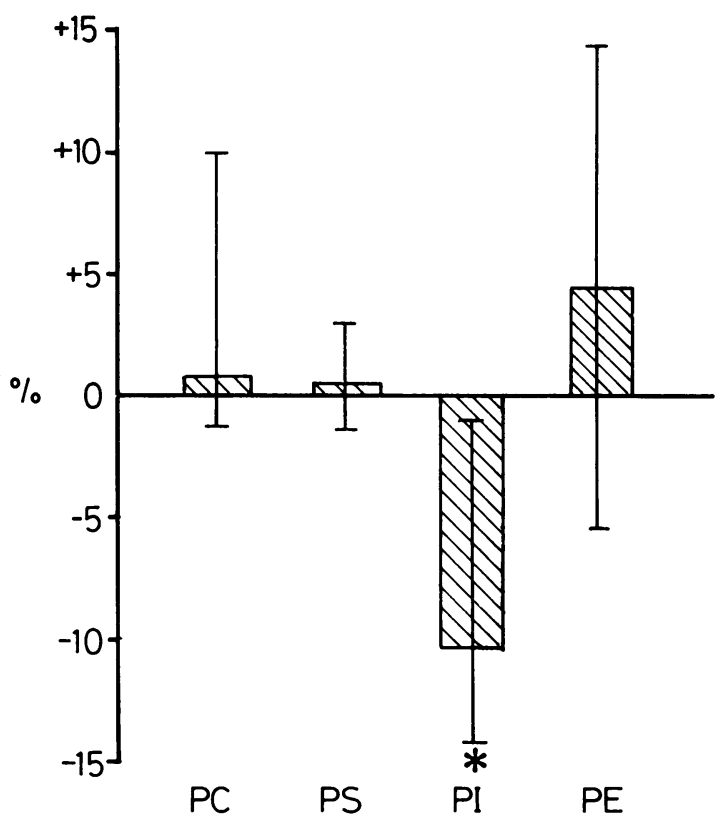

Fig. 2 Change in relative distribution of arachidonic acid in the different phospholipid fractions after stimulation with bradykinin $\left(10^{-7} \mathrm{M}, 10 \mathrm{~min}\right)$. Phosphatidylcholine $(P C)$, phosphatidylserine (PS), Phosphatidylinositol (PI), and phosphatidylethanolamine (PE). Values are given as medians with ranges (bars) for 10 experiments. ${ }^{*} p<0 \cdot 03$.

$\left(2 \cdot 6-9.9 \times 10^{2} \mathrm{~Bq} / 5 \times 10^{6}\right.$ cells) corresponding to $20 \cdot 3 \%(15 \cdot 4-24 \cdot 3 \%)$ of the $1-{ }^{14} \mathrm{C}-\mathrm{AA}$ incorporated into phospholipids.

Analysis of the distribution of radioactivity within the cells before and after stimulation with $\mathrm{BK}$ revealed that AA was mobilised primarily from PI (Fig. 2) $(\mathrm{p}<0.03)$, whereas no detectable alterations in PC, PE, or phosphatidylserine (PS) were found (Fig. 2). By contrast, A23187 caused a relative decrease in radioactivity within PC, PE, and PI by $32 \%(18-50 \% ; \mathrm{p}<0.01), 27 \%(12-45 \% ; \mathrm{p}<0.02)$,

Table 2 Total amount of radioactivity (arachidonic acid and its metabolites) released from phosphatidylinositol in $1-{ }^{14} \mathrm{C}$-arachidonic acid labelled neutrophils during control conditions and after challenge with bradykinin $\left(10^{-7} \mathrm{M}\right)$, or 5 -hydroxytryptamine $\left(10^{-7} \mathrm{M}\right)$ for 10 minutes $(n=10)$. Values are given as medians with ranges in brackets

\begin{tabular}{lll}
\hline & $n$ & $\begin{array}{l}\text { Released radioactivity } \\
\left(10^{2} \mathrm{~Bq} / 5 \times 10^{6} \text { cells }\right)\end{array}$ \\
\hline Controls & 10 & $1 \cdot 7(1 \cdot 1-2 \cdot 2)$ \\
Bradykinin & 10 & $2 \cdot 6^{*}(2 \cdot 0-3 \cdot 5)$ \\
5-hydroxytryptamine & 10 & $1 \cdot 6(0 \cdot 8-1 \cdot 9)$
\end{tabular}

${ }^{*} \mathrm{p}<0.01$ compared with controls and 5-hydroxytryptamine. 
and $11 \%(0-28 \% ; p<0.05)$, respectively, indicating that AA was released from these three phospholipid pools. Because only small amounts of PS were detected it cannot be excluded that this pool may be responsible for AA release as well.

In non-stimulated PMNs there was no detectable amount of $\mathrm{LTB}_{4}$, but trace amounts of 5-HETE was observed.

Bradykinin $\left(10^{-9}-10^{-6} \mathrm{M}\right)$ caused a dose dependent increase in the release of both lipoxygenase products, which reached a maximum at $10^{-7} \mathrm{M}$ (Fig. $3)$. The release corresponded to $2 \cdot 8 \%(2 \cdot 2-6 \cdot 6 \%)$ and $2.3 \%(0 \cdot 7-4.9 \%)$ of the total radioactivity released as far as 5-HETE and $\mathrm{LTB}_{4}$ are concerned, whereas A23187 resulted in formation of 5-HETE and $\mathrm{LTB}_{4}$ corresponding to $14.9 \%(9 \cdot 5-19 \%)$ and $5 \cdot 3 \%(2 \cdot 0-7 \cdot 6 \%)$, respectively, of the total radioactivity released.

5-HT $\left(10^{-8}-10^{-4} \mathrm{M}\right)$ caused no detectable release of lipoxygenase products (Fig. 1).

The difference in specific activity of ${ }^{14} \mathrm{C}$ metabolites, as assessed by high-pressure liquid chromatography for evaluation of the homogeneity of radiolabelling, was negligible wiz $5.4 \times 10^{8} \mathrm{~Bq} /$ $\mathrm{mmol}\left(5 \cdot 1-6.9 \times 10^{8} \mathrm{~Bq} / \mathrm{mmol}\right)$ and $6 \cdot 3 \times 10^{8} \mathrm{~Bq} / \mathrm{mmol}$ $\left(4 \cdot 8-7 \cdot 4 \times 10^{8} \mathrm{~Bq} / \mathrm{mmol}\right)$ for $\mathrm{BK}$ and $\mathrm{A} 23187$, respectively.

\section{Discussion}

These results show that concentrations of BK, comparable with those measured in plasma $\left(10^{-9}-10^{-6} \mathrm{M}\right)$, stimulates 5-lipoxygenation of AA in human PMNs, in addition to increasing the release of AA from PI. By contrast, the calcium dependent neurotransmitter, 5-HT, has no effect on AA release and 5-lipoxygenation in the concentration range used. The amount of $\mathrm{LTB}_{4}$ produced by $5 \times 10^{6}$ $\mathrm{PMNs}$, in response to optimal challenge with $\mathrm{BK}$, resulted in a median concentration - that is, $11 \cdot 1 \mathrm{nM}$, within the range which stimulates chemotaxis, ${ }^{12}$ whereas the less potent chemoattractant, 5-HETE, did not reach concentrations range sufficiently high to stimulate chemotaxis. ${ }^{12}$

The mechanism by which $B K$ stimulates the release and metabolism of AA in human PMNs has not yet been defined, but is probably dependent of stimulation of specific receptors on the external surface of the cells. ${ }^{242526} 5-\mathrm{HT}$, which has been reported earlier to increase PI turn-over in other cell types, ${ }^{27}$ had no effect on AA release and metabolism in human PMNs, which may be caused by lack of specific receptors.

On the other hand, the calcium ionophore, A23187, caused a high release of radio-labelled AA originating in both PI, PC, PE, and probably also PS.

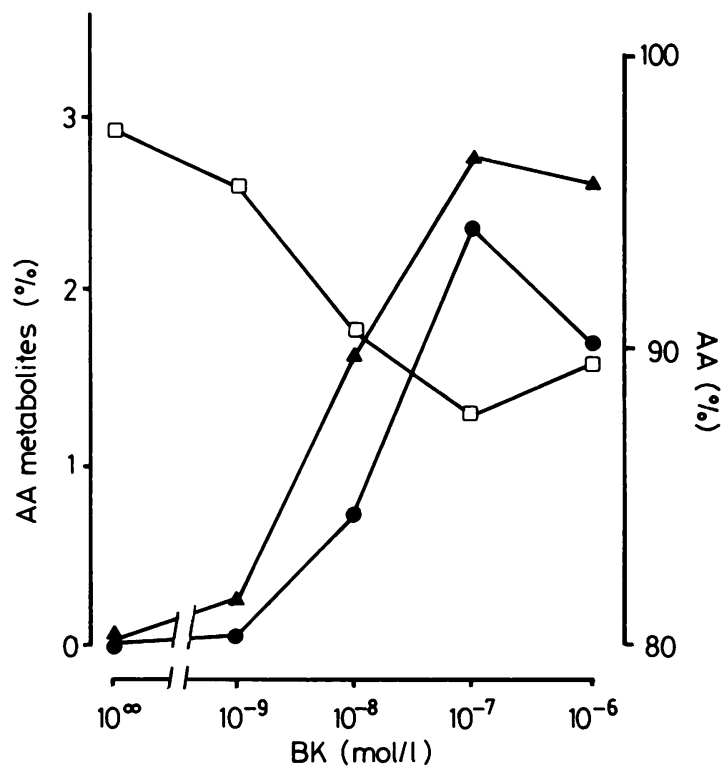

Fig. 3 Relative amounts of radioactive arachidonic acid (), leukotriene $B_{4}(\mathrm{O})$, and 5-hydroxyeicosatetraenoic acid $(\Delta)$ released during incubation of $1-{ }^{14} C$-arachidonic acid labelled neutrophils with increasing concentrations of bradykinin for 10 minutes $(n=10)$.

At maximum stimulation with A23187 (10 $\mu \mathrm{M}, 15$ min) the synthesis of $\mathrm{LTB}_{4}$ was approximately 13 times higher than that obtained with $\mathrm{BK} 10^{-7} \mathrm{M}$.

Conflicting reports concerning $\mathrm{BK}$ induced release of AA from phospholipids have been published. Thus it has been reported that AA is released from $\mathrm{PI}, \mathrm{PC}$, and PE in tumour cells, ${ }^{28}$ and from cells of kidney cortex and medulla, ${ }^{29}$ while others have found that $\mathrm{BK}$-induced $\mathrm{AA}$ release arise from mainly $\mathrm{PI}^{30}$ or PC synthesised by the methylation pathway. ${ }^{31}$

As the present study suggests that BK initiates formation of lipoxygenase products in human PMNs by a specific mechanism, whereas A23187 accelerates 5-lipoxygenation through a mechanism, which does not require a specific receptor, these results may be relevant for the understanding of the pathophysiology of inflammatory disorders, such as the inflammatory bowel diseases. In these conditions plasma concentrations of kinins are closely related to the onset of vasomotor and gastrointestinal symptoms ${ }^{32-35}$ and it is well established that inflammation is associated with the formation of kinins. ${ }^{36}{ }^{37}$ Accordingly, many factors may contribute to raised kinin concentrations. Thus it has been shown that the inflamed colonic tissue from patients with ulcerative colitis contains abnormally high concentrations of the BK releasing enzyme, kallikrein, ${ }^{38}$ and that plasma and tissue concentrations of the kinin degrading 
enzyme, peptidyl-dipeptidase, are depressed in patients with Crohn's disease ${ }^{39}$ Furthermore, plasma concentrations of $\alpha_{2}$-macroglobulin, which inhibits kallikrein, are low in patients with Crohn's disease. ${ }^{+0}$

We would tentatively conclude, therefore, that the results of the present study offer evidence for the view that $\mathrm{BK}$, but not 5-HT, adds to the formation of lipoxygenase products, such as $\mathrm{LTB}_{4}$, by binding to specific receptors on the external surface of PMNs, thus promoting inflammation as well as diarrhoea in inflammatory bowel disease.

The authors are grateful to Helma Furhauge, Hanne Kargaard, and Bente Nielsen for skilful technical assistance. This work was supported by grants from The Foundation of 1870 , Handelsgartner Ove Villiam Buhl Olesen's og ægtefælle Edith Buhl Olesen's Foundation, Direktør Jacob Madsen's og hustru Olga Madsen's Foundation, and The Danish Medical Research Council.

\section{References}

1 Donowitz M. Arachidonic acid metabolites and their role in inflammatory bowel disease. Gastroenterology 1985; 88: 580-7.

2 Sharon P, Stenson WF. Metabolism of arachidonic acid in acetic acid colitis in rat. Similarity to human inflammatory bowel disease. Gastroenterology 1985; 88: 55-63.

3 Zipser RD, Patterson JB, Kao HW, Hauser CJ, Locke $\mathrm{R}$. Hypersensitive prostaglandin and thromboxane response to hormones in rabbit colitis. Am J Physiol 1985; 249: G457-63.

4 Rampton DS, Sladen GE, Youlten LJ. Rectal mucosal prostaglandin $E_{2}$ release and its relation to disease activity, electrical potential difference, and treatment in ulcerative colitis. Gut 1980; 21: 591-6.

5 Lauritsen K, Hansen J, Bytzer P, Bukhave K, RaskMadsen J. Effects of sulfasalazine and disodium azodisalicylate on colonic $\mathrm{PGE}_{2}$ concentrations determined by equilibrium in vivo dialysis of faeces in patients with ulcerative colitis and healthy controls. Gut 1984; 25: 1271-8.

6 Sharon P, Stenson WF. Enhanced synthesis of leukotriene $\mathrm{B}_{4}$ by colonic mucosa in inflammatory bowel disease. Gastroenterology 1984; 86: 453-60.

7 Lauritsen K, Laursen LS, Bukhave K, Rask-Madsen J. Effects of topical 5-aminosalicylic acid and prednisolone on prostaglandin $E_{2}$ and leukotriene $B_{4}$ levels determined by equilibrium in vivo dialysis of rectum in relapsing ulcerative colitis. Gastroenterology 1986; 91: 837-44.

8 Nixon JB, Riddell RH. Histopathology of ulcerative colitis. In: Allan RN, Keighley MRB, AlexanderWilliams J, Hawkins C, eds. Inflammatory bowel disease. Edinburgh: Churchill Livingstone, 1983: 194-209.

9 Nielsen OH, Bukhave K, Ahnfelt-Rønne I, Elmgreen J.
Arachidonic acid metabolism in human neutrophils. Lack of effect of cyclosporine A. Int J Immunopharmacol 1986; 8: 419-26.

10 Poubelle P, Beaulieu AD, Nadeau M, Laviolette $M$, Borgeat $P$. The metabolism of arachidonic acid through the lipoxygenase pathways in human phagocytes. $A d v$ Inflam Res 1986; 11: 17-29.

11 Goetzl EJ, Payan DG, Goldman DW. Immunopathogenetic roles of leukotrienes in human diseases. J Clin Immunol 1984; 4: 79-84.

12 Nielsen $\mathrm{OH}$, Elmgreen J. Activation of neutrophil chemotaxis by leukotriene $\mathrm{B}_{4}$ and 5-hydroxyeicosatetraenoic acid in chronic inflammatory bowel disease. Scand J Clin Lab Invest 1987; 47: 605-11.

13 Majerus PW, Connolly TM, Deckmyn H, Ross TS, Bross TE, Ishii H, Bansal VS, Wilson DB. The metabolism of phosphoinositide-derived messenger molecules. Science 1986; 234: 1519-26.

14 McKean ML, Smith JB, Silver MJ. Formation of lysophosphatidylcholine by human platelets in response to thrombin. Support for the phospholipase $\mathrm{A}_{2}$ pathway for the liberation of arachidonic acid. J Biol Chem 1981; 256: $1522-4$.

15 Rask-Madsen J. Eicosanoids and their role in the pathogenesis of diarrhoeal diseases. Clin Gastroenterol 1986; 15: 545-66.

16 Bell RL, Kennerly DA, Stanford N, Majerus PW. Diglyceride lipase: a pathway for arachidonate release from human platelets. Proc Natl Acad Sci 1979; 76: 3238-41.

17 Prescott SM, Majerus PW. Characterization of 1,2diacylglycerol hydrolysis in human platelets. Demonstration of an arachidonyl-monoacylglycerol intermediate. J Biol Chem 1983; 258: 764-9.

18 Berridge MJ, Irvine RF. Inositol triphosphate, a novel second messenger in cellular signal transduction. Nature 1984; 312: 315-21.

19 Nishizuka $Y$. The role of protein kinase $\mathrm{C}$ in cell surface signal transduction and tumour promotion. Nature 1984; 308: $693-8$.

20 Beubler E, Bukhave K, Rask-Madsen J. Significance of calcium for the prostaglandin $E_{2}$-mediated secretory response to 5-hydroxytryptamine in the small intestine of the rat in vivo. Gastroenterology 1986; 90: 1972-7.

21 Böyum A. Isolation of leucocytes from human blood. Scand J Clin Lab Invest 1968; 21: suppl 97: 9-29.

22 McConn R, Wasserman F, Haberland G. The kallikreinkinin system in the acutely-ill: Changes in plasma kininogen in acutely-ill patients. Adv Exp Med Biol 1983; 156: 1019-35.

23 Donowitz M, Tai YH, Asarkof N. Effect of serotonin on active electrolyte transport in rabbit ileum, gallbladder, and colon. Am J Physiol 1980; 239: G463-72.

24 Roch-Arveiller M, Caranikas S, Regoli D, Giroud J-P. Effects of bradykinin and some of its fragments on smooth muscles and chemotaxis. Eur J Pharmacol 1983; 88: 99-103.

25 Roscher AA, Manganiello VC, Jelsema CL, Moss J. Autoregulation of bradykinin receptors and bradykinininduced prostacyclin formation in human fibroblasts. J Clin Invest 1984; 74: 552-8.

26 Manning DC, Snyder SH, Kachur JF, Miller RJ, Field 
M. Bradykinin receptor-mediated chloride secretion in intestinal function. Nature 1982; 299: 256-9.

27 Litosch I, Saito Y, Fain JN. 5-hydroxytryptamine stimulated arachidonic acid release from labelled phosphatidylinositol in blowflow salivary glands. Am J Physiol 1982; 243: C222-6.

28 Schremmer JM, Blank ML, Wykle RL. Bradykininstimulated release of $\left({ }^{3} \mathrm{H}\right)$-arachidonic acid from phospholipids of $\mathrm{HSDM}_{1} \mathrm{C}_{1}$ cells. Prostaglandins 1979; 18: 491-505.

$29 \mathrm{Raz}$ A, Schwartzman M. Bradykinin-stimulated differential incorporation of arachidonic acid into lipids of kidney cortex and medulla. Biochem Pharmacol 1983; 32: 2843-6.

30 Bell RL, Baenziger NJ, Majerus PW. Bradykininstimulated release of arachidonate from phosphatidylinositol in mouse fibrosarcoma cells. Prostaglandins 1980; 20: 269-74.

31 Bareis DL, Manganiello VC, Hirata F, Vaughan M, Axelrod J. Bradykinin stimulates phospholipid methylation, calcium influx, prostaglandin formation, and cAMP accumulation in human fibroblasts. Proc Natl Acad Sci 1983; 80: 2514-8.

32 Oates JA, Melmon K, Sjoerdsma A, Gillespie L, Mason DT. Release of a kinin peptide in the carcinoid syndrome. Lancet 1964; i: 514-7.
33 Zeitlin IJ, Smith AN. 5-hydroxyindoles and kinins in the carcinoid and dumping syndromes. Lancet 1966; ii: 986-91.

34 Wong PY, Talamo RC, Babior BM, Raymond GG, Colman RW. Kallikrein-kinin system in a postgastrectomy dumping syndrome. Ann Intern Med 1974; 80: 577-81.

35 Cuschieri A, Onabanjo OA. Kinin release after gastric surgery. Br Med J 1971; 3: 565-6.

36 Lewis GP. Kinins in inflammatory and tissue injury. In: Erdös EG, ed. Handbook of experimental pharmacology. Berlin: Springer-Verlag, 1970: 516-30.

37 Sundsmo JS, Fair DS. Relationships among the complement, kinin, coagulation and fibrinolytic systems in the inflammatory reaction. Clin Physiol Biochem 1983; 1: 225-84.

38 Zeitlin IJ, Smith AN. Mobilization of tissue kallikrein in inflammatory disease of the colon. Gut 1973; 14: 133-8.

39 Silverstein E, Fierst SM, Simon MR, Weinstock JV, Friedland J. Angiotensin-converting enzyme in Crohn's disease and ulcerative colitis. Am J Clin Pathol 1981; 75: 175-8.

40 Brown DJC, Khan JA, Copeland G, Jewell DP. Alpha 2-macroglobulin in patients with inflammatory bowel disease. J Clin Lab Immunol 1980; 4: 53-7. 